\title{
WestVirginiaUniversity
}

THE RESEARCH REPOSITORY @ WVU

Graduate Theses, Dissertations, and Problem Reports

2004

\section{Pentosidine as a biomarker for age in birds and museum- prepared study skins}

Jesse A. Fallon

West Virginia University

Follow this and additional works at: https://researchrepository.wvu.edu/etd

\section{Recommended Citation}

Fallon, Jesse A., "Pentosidine as a biomarker for age in birds and museum-prepared study skins" (2004). Graduate Theses, Dissertations, and Problem Reports. 2007.

https://researchrepository.wvu.edu/etd/2007

This Thesis is protected by copyright and/or related rights. It has been brought to you by the The Research Repository @ WVU with permission from the rights-holder(s). You are free to use this Thesis in any way that is permitted by the copyright and related rights legislation that applies to your use. For other uses you must obtain permission from the rights-holder(s) directly, unless additional rights are indicated by a Creative Commons license in the record and/ or on the work itself. This Thesis has been accepted for inclusion in WVU Graduate Theses, Dissertations, and Problem Reports collection by an authorized administrator of The Research Repository @ WVU. For more information, please contact researchrepository@mail.wvu.edu. 


\title{
Pentosidine as a Biomarker for Age in Birds and Museum Prepared Study Skins
}

\author{
Jesse A. Fallon \\ Thesis submitted to the \\ Davis College of Agriculture, Forestry and Consumer \\ Sciences \\ at West Virginia University \\ in partial fulfillment of the requirements \\ for the degree of \\ Master of Science \\ Animal and Veterinary Sciences \\ Hillar Klandorf, Chair \\ Kenneth P. Blemings \\ James T. Anderson \\ Department of Animal \& Veterinary Sciences \\ Morgantown, West Virginia \\ 2004
}

Keywords: Pentosidine, Advanced Glycation Endproducts, Aging, Ruffed grouse, Double-crested cormorants, Study skins

Copyright 2004 Jesse A. Fallon 


\section{ABSTRACT \\ Pentosidine as a Biomarker for Age in Birds and Museum Prepared Study Skins}

\section{Jesse A. Fallon}

The phenomenon of aging is progressive, irreversible and universal to all living things. One unavoidable outcome of aging is the modification of proteins by sugars, which, through a non-enzymatic process, can lead to the formation of crosslinked compounds termed advanced glycation endproducts. One such endproduct, pentosidine (Ps), is an indicator, or biomarker, of biological age. Because most birds have no reliable markers of age beyond adulthood, this investigation examines the accumulation of Ps as an estimator of chronological age in birds. The first study herein examines interspecies comparison of Ps accumulation in Ruffed grouse and Double-crested cormorants. The second investigates the stability of Ps in museum prepared study skins. Accurate age information can contribute to our understanding of population demographics, could aid species recovery programs, and provide insights into longevity now understood entirely from banding programs and captive birds. 


\section{Dedication}

This work is dedicated to my wife, Katie Fallon. Her unending love, inspiration, tolerance and support have made its completion possible. 


\section{Acknowledgments}

Special thanks to $\mathrm{Dr}$. Ken Blemings and $\mathrm{Dr}$. Jim Anderson for generously providing their time, knowledge and critical eye.

Thanks also to $\mathrm{Dr}$. Bill Radke for donating his study skin preparation skills and avian expertise.

Thanks to Brian Dorr, Robert Cochrane, George Seidel, Elizabeth Falkenstein and my fellow graduate students for their significant contributions.

Finally, I would like to express my sincere appreciation to Hillar Klandorf, who not only provided this academic opportunity and served expertly in his advisory role, but also provided me with frankness, friendship, and a lifelong hobby. 


\section{Table of Contents}

Chapter 1

Literature review

$\ldots \ldots 1$

Chapter 2

Interspecies comparison of

pentosidine accumulation in birds $\ldots \ldots 16$

Chapter 3

Stability of pentosidine in

museum prepared study skins

$\ldots \ldots 33$

Chapter 4

Conclusions

$\ldots \ldots 52$

Appendices

A: Ruffed grouse $\ldots \ldots 54$

B: Double-crested cormorants

$\ldots \ldots 5$

C: Study Skins

$\ldots \ldots 56$

D: Round the body grouse

$\ldots . .57$

Chapter 5

Literature cited

$\ldots \ldots 58$ 


\section{Literature review}

The phenomenon of aging is progressive, irreversible and universal to all living organisms. Though it is a basic, unavoidable, biological progression beginning at birth and ending only with death, its exact causes and mechanism still elude us. Despite considerable progress in the development of testable hypotheses concerning aging in an evolutionary context, a unifying theory of molecular and physiological aging has not yet been reached. As with most scientific endeavors, perhaps the mystery of aging can be unraveled piece by piece, in small steps. Like a great knot, each loop and kink must be pulled through in turn, until finally we have a cord that can be pulled straight, with a definitive beginning and end. With this approach in mind, we may begin our unraveling by examining certain cues or markers of the aging process.

On an evolutionary scale, we can use chronological age as a measure of senescence within populations. However, this may not be a reliable index of the extent of senescence in an individual because the rate of aging varies considerably among individuals within any given species (Baker and Sprott 1988). This line of reasoning has led to the concept of biological age as distinct from 
chronological age, and therefore an interest in developing a means to measure biological age within an individual arose. Such a quantitative biomarker would allow not only for estimation of biological age, but, because aging increases susceptibility to disease and finally to death, also as a predictor of future occurrence of age-associated diseases, impending mortality, and maximum longevity of species (Masoro 1988).

Several potential biomarkers of age have been examined, and some of these indicators of biological age do correlate with chronological age within individuals. Among these, physical changes in long lived proteins such as collagen have been among the most promising biomarkers of aging. These physical changes in collagen occurring with increasing age are in part the result of posttranslational modifications of sugars - modifications that have been known about for quite some time (Bunn and Higgins 1981).

\section{Maillard Reaction}

In a brief 1912 paper, Louis Camille Maillard (1912) described his observation that gently heating sugars and amino acids in water resulted in a yellow-brown colored product. It seems unlikely that the scientific community of France, even in 1912, would have been surprised or 
impressed by Maillard's results. Over the course of the next 90 years, however, the reaction that now bears his name proves consequential for many disciplines. Indeed, Maillard chemistry has been intensely studied by food scientists, physiologists, chemists, physicians and many others.

The Maillard reaction is now understood to represent a group of biochemical non-enzymatic browning reactions between aldehydes, ketones, or reducing sugars and amino acids, peptides or proteins (Monnier and Cerami 1981). While the precise nature of Maillard chemistry has yet to be fully defined, the immediate end-products of this reaction are known to undergo several alterations. Early work by Amadori (1931), Kuhn and Weygand (1937), Simon and Kraus (1970), and Heyns et al.(1957) uncovered the initial series of reactions in which the carbonyl moiety of the sugar molecule reacts with a biological amine such as an amino acid or the lysine residue of a protein forming a Schiff base (Fayle and Gerrard 2002). This Schiff base is unstable, and can undergo rearrangements resulting in what is termed an Amadori product, a reasonably stable aminoketose (Cerami et al. 1987). An example of this portion of the Maillard reaction can be seen in Figure 1 . 

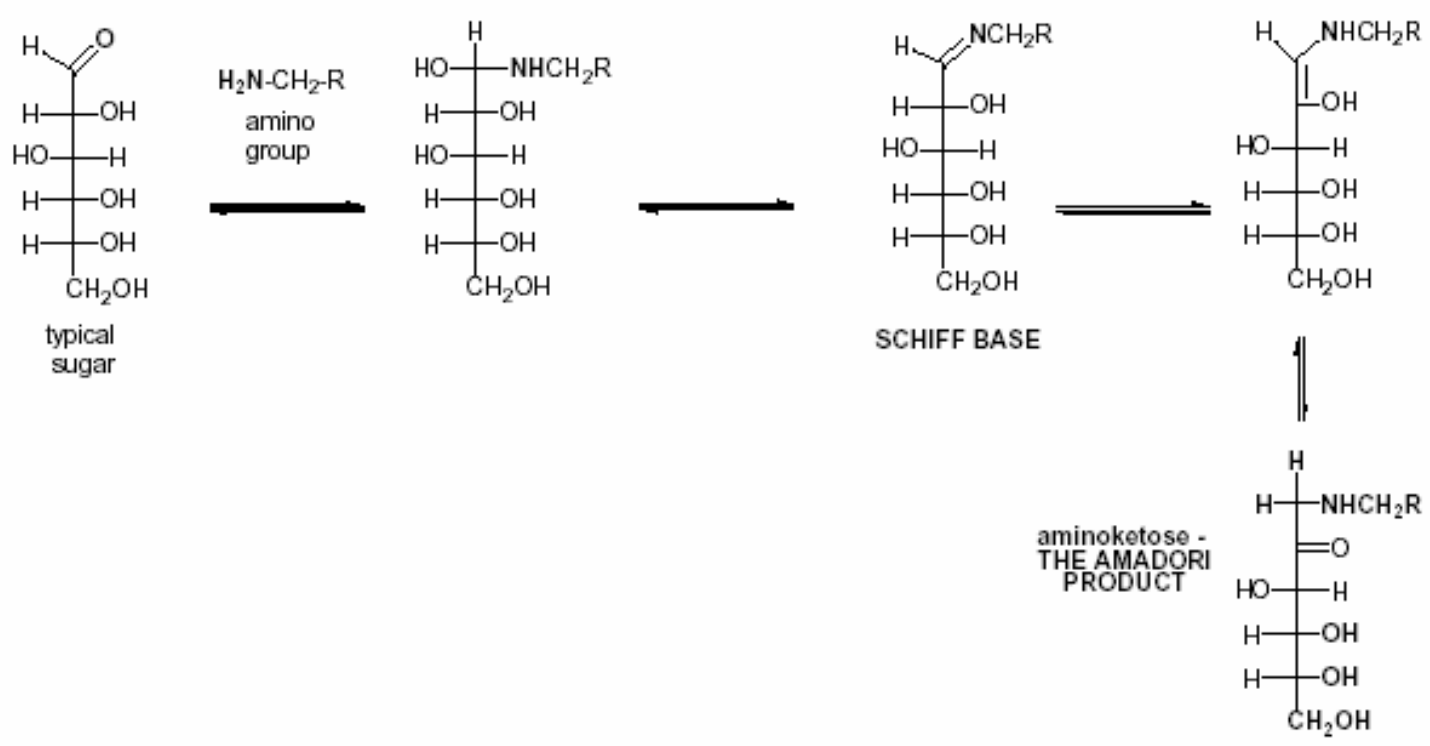

Figure 1. Maillard chemistry: sugar reacting with amino groups to form Amadori product - as presented by Fayle and Gerrard (2002).

The Amadori products can then undergo further interand intramolecular rearrangements. These final rearrangements produce a variety of structurally diverse compounds possessing distinctive fluorescent and crosslinking properties known as advanced Maillard products or, more commonly, advanced glycation end products (AGEs) (Monnier et al. 1984). Although Louis Camile Maillard described reactions between reducing sugars and amines more than 90 years ago, only recently did an appreciation for the formation of AGEs in vivo begin to fully develop. 


\section{Advanced Glycation Endproducts}

Advanced glycation endproducts and AGE crosslinks are the final destinations of the Maillard reactants (Monnier et al. 1984). Found to form in all proteins, AGEs are stable, irreversible, and therefore cumulative with age in vivo. This accumulation is known to have adverse affects on the functionality of proteins, lipids, and DNA (Ledl and Schleicher 1990). Not surprisingly, AGEs accumulate most noticeably in long-lived tissues such as lens crystallins and collagen (Monnier and Cerami 1983; Kohn et al. 1984). In the eyes, formation of AGEs contributes to the development of cataracts, while in collagen to the yellowing and loss of elasticity, causing stiffness in joints and wrinkling of skin. Numerous studies have demonstrated the accumulation of AGEs with age in the collagen of mice, birds, and humans. Because of the cumulative nature of these compounds AGEs are now considered a biomarker of biological age (Bellmunt et al. 1995; Pokharna et al. 1995). While interest in the formation and accumulation of AGEs spans many fields, they have perhaps been most closely examined in human medicine. 


\section{Advanced Glycation Endproducts in Diabetes Research}

Because of their inability to maintain stable levels of blood sugar, and the role of sugar modification in AGE formation, it was proposed that diabetics should accumulate AGEs at a greater rate than non-diabetics (Odetti et al. 1992). The physiological relevance of AGE accumulation in diabetics has been confirmed by observations revealing that antibodies prepared against AGE-proteins react with antigens in tissue proteins, that these AGE antigens increase in human lens proteins with age, and that they are present at higher age-adjusted levels in human serum (Ikeda et al. 1998; Makita et al. 1992). Additionally, diabetic rats were found to develop AGE antigens more rapidly than normal rats in aortic and renal collagen (Makita et. al. 1992). Advanced glycation endproduct accumulation therefore, may be a causative agent in some of the symptoms of late-stage diabetes (Bucala and Cerami 1992).

This line of reasoning led to examination of pathobiochemical pathways of AGE formation in hopes of uncovering interventive strategies. These investigations revealed that activated oxygen species (ROS) are involved in the formation of AGEs (Baynes 1991). The term "glycoxidation," coined by Baynes in 1991, is descriptive of the glycation and oxidation steps required for formation 
of at least some AGEs. Furthermore, binding of an intracellular receptor to AGEs, termed RAGE, has been has been shown to cause depletion of cellular antioxidantdefense mechanisms as a consequence of the generation of ROS, leading to increased cellular oxidative stress (Bierhaus et al. 1997). Advanced glycation endproducts may then be biomarkers not only for age, but also for oxidative stress (Suzuki et al. 1999).

While research with human diabetics has helped to uncover the pathways to formation and structures of several of these end products, it is likely that a great many more have yet to be uncovered. The few that have been examined extensively include carboxymethl lysine (CML), pyrraline, and pentosidine (Dyer et al. 1993; Hayase et al. 1989; Sell and Monnier 1989a). Along with CML, the AGE pentosidine has been of particular interest as a biomarker for diabetic complications and aging in general (Sell et al. 1992; Sell and Monnier 1989a).

\section{Pentosidine}

Pentosidine (Ps), one of the most heavily researched AGEs, was first isolated from human dura mater in 1989, in which it was found to accumulate with age (Sell and Monnier 1989b). It is a highly fluorescent AGE crosslink 
containing an arginine and lysine residue bound by a molecule of ribose (Figure 2). While its formation can be elicited in vitro from pentoses (hence its name), hexoses, ascorbate, and a variety of Amadori products, the major carbohydrate source in vivo has yet to be identified (Sell and Monnier 1989a; Dyer et al. 1993). Again, its formation is dependent on oxidation and is considered both an AGE and a glycoxidation product (Baynes 1991). Although Ps represents only a small portion total senescent crosslinking, it is considered an excellent biomarker for non-enzymatic modification of long-lived proteins, providing insight into the role of the Maillard reaction in aging and disease (Dyer et al. 1993).

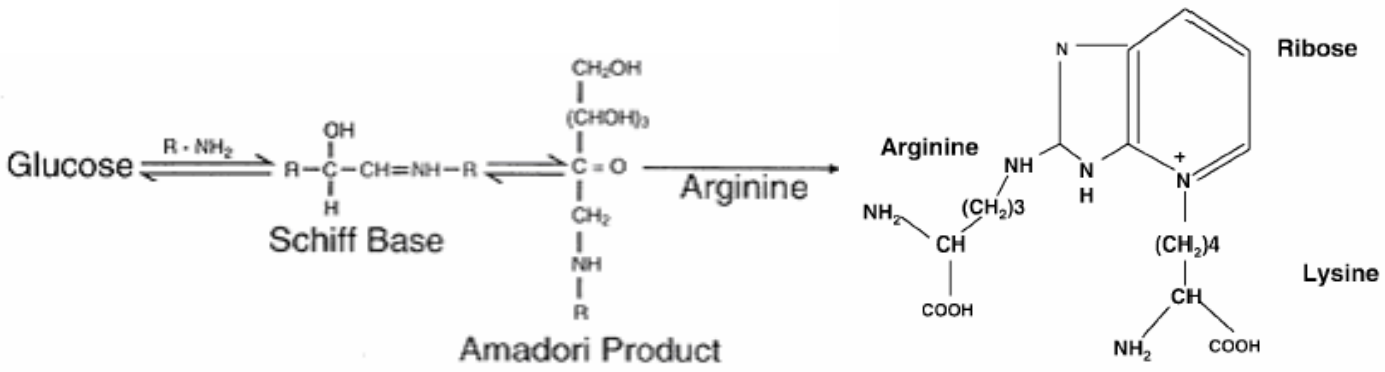

Figure 2. Proposed in vivo formation and structure of pentosidine - adapted from Sell et al. 2000

Numerous studies have demonstrated the accumulation of Ps in long-lived tissue proteins. This progressive 
increase has been demonstrated in human skin, dura mater, and cartilage (Sell and Monnier 1996; Dyer et al. 1993), as well as in the skin of rodents, cows, pigs, dogs and monkeys (Sell and Monnier 1996). Furthermore, these studies suggested that Ps accumulation rates are inversely related to longevity. That is, species that tend to have shorter lifespans accumulate Ps more rapidly than those with longer maximum lifespans.

While these findings were not absolute and maximum levels of Ps between species varied greatly, they do suggest that a process that is reflected in the age-related accumulation of Ps may operate in the determination of maximum longevity. If this is the case, a strong correlation between the accumulation of AGEs like Ps and the age of individual animals should become apparent. Indeed, the relationship between Ps accumulation and age has been shown to be strongly correlated. Sell et al. (1992) fitted the accumulation of Ps in pmol/mg collagen with age in the skin of humans with a linear regression model $\left(R^{2}=0.73\right)$. The same laboratory has more often fitted curvilinear models to a variety of mammalian species with similar strong correlations (Sell et al. 1996). Additionally, diabetics have been shown to accumulate more Ps then non-diabetic humans, again suggesting that the lack 
of metabolic control leads to increased glycation and thus an increase in AGEs (Sell et al. 1992).

It seems clear that a correlation exists between Ps accumulation in collagen and the age of individual animals, at least in mammalian species. It is difficult to imagine, however, that a similar correlation should not be present in other, non-mammalian species as well.

\section{Pentosidine Quantification in Birds}

AGEs have been quantified in a few species of birds including turkeys (Rendell et al. 1985) and hummingbirds (Beuchat and Chong 1998). Iqbal et al. (1999b) confirmed the accumulation of Ps in ad-libitum-fed broiler breeder hens. As expected, concentrations of Ps were found to increase with age. This study also suggested that birds accumulate Ps more slowly than mammals with similar metabolism, supporting the link between less rapid AGE formation and longevity. Examining a variety of avian species, Chaney et al. (2003) described a linear increase in Ps concentration ( $\mathrm{pmol} / \mathrm{mg}$ collagen) with age. The work also suggested that by applying this linear correlation to individual birds, the age of adult birds could be estimated. 


\section{Avian Aging}

Most mammals exhibit outward morphological signs of aging which include wrinkling of exposed skin, graying of hair around the face and muzzle, tartar buildup or wear of molars, and reduction in bone density. Unlike their furry, endothermic counterparts, birds have evolved in such a way that outward signs of aging do not develop. Evolution for flight has produced skin that is covered by feathers, hollow bones, and the replacement of teeth and jawbones with a bill. While the experienced ornithologist, and in fact the novice bird watcher, can readily discern a juvenile bird from its adult counterpart through alterations in plumage color or feather wear, or by examining rectrix (tail feather) or spur length, once the threshold into adulthood has been crossed, no morphological signs of aging exist (Winker, 2000; Greenburg et al. 1972).

Current age data therefore must rely on leg or wing banding. While this is an accurate method, birds must be captured at a young, recognizable age, and then recovered at a later time - a labor intensive and rather protracted method. The technique developed by Chaney et al. (2003) using Ps accumulation as a biomarker of age, if applied to individual avian species, could prove invaluable to age estimation . 
The ability to estimate age would enable researchers to make inferences concerning demographics. More than simply knowledge about average and maximum lifespans, age estimation could answer questions such as, when do different species of birds become sexually mature? How does age affect territory establishment? At what age does reproductive ability reach its peak? When do fertility rates begin to decline? Are different age groups susceptible to different diseases or pathogens? These are just a few of many lines of inquiry that could benefit from a technique for age estimation in adult birds.

\section{Birds as Models for Aging}

Beyond gaining a greater understanding of avian physiology and demographics through the application of a technique for age estimation, perhaps we can learn more about the aging process in general. All animals are born, inevitably die, and all the while they are aging. Because of the endogenous nature of aging, animal models can be used to help us better understand what factors lead to and what mechanisms cause aging.

Avian models in particular give us a unique glimpse into metabolic factors that are believed to encourage biological aging. For example, birds have overall 
metabolic rates as much as 2.5 times higher than those of mammals, with lifetime energy expenditures reaching 5 to 15 times greater (Holmes 1995, 2001). This presumably exposes them to a higher rate of free radical production, and should lead to accelerated tissue damage (Del Maestro 1980). Birds also maintain core body temperatures approximately $3^{\circ} \mathrm{C}$ higher, as well as carrying much higher levels of blood glucose (two- to four-fold higher) than mammals (Holmes, 1995). These factors should, according to current understanding, be liabilities toward biochemical aging and lead to a more rapid accumulation of deleterious by-products, such as AGEs, thereby rendering birds more susceptible to age-dependant degenerative processes. Cumulatively, these attributes should lead to a reduction in overall life expectancy. Birds, then, should have shorter maximum lifespans than comparatively sized mammals. Surprisingly, the exact opposite is the case. Birds are strikingly longer lived than mammals of comparative size (Lindstedt and Calde 1976). Longevity records from wild birds indicate that Mourning doves (Zenaida macroura) can live to at least 31 years of age and Red-tailed hawks (Buteo jamaicensis) to 29 years (Klimkiewicz and Futcher 1989). One Layson albatross (Diomedea immutabilis) lived to the ripe old age of 53 (Fisher 1975). Unconfirmed 
reports of Psitticines in captivity living into their $80^{\prime}$ 's and $90^{\prime} \mathrm{s}$ abound. This remarkable longevity becomes all the more fascinating when coupled with the physiology of class Aves, and in fact defies much of what we believe influences maximum lifespans.

Using birds as models for aging may help reveal biological techniques that organisms use to slow the aging process. If this is the case, perhaps these techniques could be applied to other species, humans for instance, who have had intense interest in slowing or preventing the aging process since before Ponce de Leon searched in vain for the fountain of youth. While it is unlikely that avian models can bring us to immortality, understanding how birds cope with their metabolic disabilities may contribute to the prevention of age-related diseases in humans. Moreover, because all eukaryotic organisms age, information obtained concerning aging in birds should parallel aging in other animals.

The remarkable longevity in the majority of birds does not, however, hold true for all species. Galliformes such as domestic chickens (Gallus gallus), Wild turkey (Meleagris gallopavo), and Ruffed grouse (Bonasa umbellus) have much shorter lifespans than those from the families Columbidae, Falconidae, Hydrobatidae, and Psitticidae. 
Because data in mammals suggest that shorter-lived species accumulate AGEs more rapidly than those with greater maximum lifespans, it stands to reason that the shorter lived gallinaceous birds should show the same trait (Sell and et al. 1996). This possibility becomes exceedingly important if the biomarker Ps is to be extrapolated to an age estimate. Therefore, interspecies comparisons of Ps accumulation will be vital to the practical application of such a technique.

This accumulation of knowledge on aging, AGEs, and birds provides a firm grasp on a kink, however small, in the metaphorical knot. The following studies continue to investigate the use of Ps accumulation as a biomarker for age in adult birds. Specifically, they examine interspecies comparison of Ps concentrations, the stability of Ps in museum prepared study skins, and variations in Ps accumulation between different locations around the body. 


\title{
INTERSPECIES COMPARISON OF PENTOSIDINE ACCUMULATION AND ITS CORRELATION WITH AGE IN BIRDS
}

\author{
Jesse A. Fallon ${ }^{1}$, Robert L. Cochrane ${ }^{1}$, Brian Dorr $^{2}$, and \\ Hillar Klandorf ${ }^{1}$ \\ ${ }^{1}$ Division of Animal and Veterinary Sciences, West Virginia \\ University, Morgantown, West Virginia 26506-6108, USA \\ hillar.klandorf@mail.wvu.edu
}

${ }^{2}$ USDA Wildlife Services, National Wildlife Research Center, Mississippi Field Station, P.0. Drawer 6099, Mississippi State University, Mississippi 39762, USA 
Abstract.-Recent studies suggest that a linear correlation exists between the age of individual birds and the accumulation of the advanced glycation endproduct pentosidine (Ps). This investigation compares Ps accumulation in skin tissue of Ruffed grouse (Bonasa umbellus) and Double-crested cormorants (Phalacrocorax auritus). Skin samples were taken from the breast of 52 Ruffed grouse of known ages ranging from a few days to ten years. Skin was cleaned of feathers and adipose tissue, acid hydrolyzed and measured for collagen content via hydroxyproline spectrophotometric assay. Ps concentrations were determined using reverse phase HPLC. Fluorescent detection (excitation 310nm, emission 385nm) revealed concentrations of Ps/mg collagen to increase curvilinearly with age $\left(R^{2}=.87, p<.0001\right)$. Additionally, a blind study of 19 Double-crested cormorants revealed a linear relationship between Ps concentrations and age $\left(R^{2}=.93\right)$. Comparison of these two species revealed a more rapid accumulation of Ps in Ruffed grouse. Accurate age information could aid species recovery programs and provide insights into longevity now understood entirely from banding programs and captive birds. 
The phenomenon of aging is progressive, irreversible and universal to all living things. One unavoidable outcome of aging is the modification of proteins by sugars, which, through a non-enzymatic process known as the Maillard reaction, can lead to the formation of crosslinked compounds termed advanced glycation endproducts (AGEs) (Cerami et al. 1987). These protein crosslinks, like the process of aging that their formation is associated with, are irreversible. Because of this stability, AGEs are cumulative in vivo, most noticeably in long-lived tissues such as collagen. One such AGE, pentosidine (PS), is a stable, fluorescent crosslink comprised of an arginine and lysine residue bound by a pentose sugar. The cumulative nature and inherent fluorescence of pentosidine make it a valuable biomarker of aging that can readily be measured in the laboratory.

Pentosidine has been found to accumulate with age in the skin collagen of a variety of mammalian species (Sell et al. 1996). Moreover, interspecies comparison of pentosidine accumulation in mammals has demonstrated that Ps accumulates at different rates in different species, and that an inverse relationship exists between maximum longevity and pentosidine (Sell et al. 1996). That is, species with shorter lifespans tend to accumulate 
pentosidine more rapidly than those with greater maximum life expectancies.

Work by Iqbal et al. (1997, 1999) confirmed the accumulation of pentosidine with age in domestic poultry. More recently, Chaney et al. (2003) found that pentosidine accumulation was linearly correlated to the age of a variety of wild bird species. These studies indicate that the accumulation of the glycoxidation product pentosidine is strongly correlated to the age of individual birds, verifying it as a biomarker for the aging process (Iqbal et al. 1999; Chaney et al. 2003). Furthermore, Chaney et al. (2003) suggested that the linear accumulation of pentosidine could be used as an estimate of the chronological age of individual birds. The variability in pentosidine concentrations associated with these data from a variety of species, however, necessitates examination between individual species.

Because most birds exhibit few or no external morphological changes beyond adulthood, current information on aging relies on banding data, a labor intensive and protracted technique. Using pentosidine as a biomarker for aging would provide insight into age related population demographics such as the onset of sexual maturity, agespecific fecundity, and the effect of age on behavior and 
susceptibility to disease (Johnsen et al. 2003; Maransky and Bildstein 2002). Additionally, because many species are strong pair-bonders, species survival programs would benefit from the ability to pair non-banded birds of similar ages.

If this technique is to be used as a chronological estimate of age in birds, and, as in the mammalian models presented by Sell et al. (1996), Ps accumulation varies between individual species with different maximum lifespan potentials, an understanding of what variations exist among avian species with varying life expectancies must be attained. For this reason, we examined the potential use of pentosidine as a biomarker to estimate the chronological age in a relatively short-lived, granivorous species, the Ruffed grouse (Bonasa umbellus). These data are compared to a blind study which examines pentosidine accumulation in a longer-lived, piscivorous species, Double-crested cormorants (Phalacrocorax auritus).

\section{Materials AND Methods}

Tissue Procurement.-Grouse samples were obtained at necropsy from West Virginia University's captive colony immediately after death. Approximately 25 grams of skin was removed from the breast of 29 male and 23 female grouse 
of known ages ranging from 33 days to 10 years. For up to one month prior to processing, samples were stored at $80^{\circ} \mathrm{C}$.

Previously banded cormorants of known ages were collected from the wild in Mississippi and Alabama by employees of the U.S. Department of Agriculture/Wildlife Services (USDA/WS) National Wildlife Research Center, from October through April of 2002-2003 and 2003-2004. Banded cormorants also were obtained from individuals and agencies taking cormorants under the U.S. Fish and Wildlife Service unlimited depredation order. Skin samples $(n=19)$ of approximately 150 grams were taken at necropsy and frozen in a sterile saline solution until assayed. Age data were not provided with the samples, which were processed immediately upon arrival.

Sample Processing. -Skin samples of approximately $2 \mathrm{~cm}^{2}$ were prepared as described by Iqbal et al. (1997) and Chaney et al. (2003). Samples were scraped and cleaned of feather shafts, adipose tissue, and circulatory vessels. Forty mg of the remaining connective tissue was minced and then delipidated in a 2:1 chloroform/methanol solution for 18 hours. Following delipidation, the residue was recovered by centrifugation and placed in $4 \mathrm{ml}$ of $1: 1$ 
water/methanol solution for 2 hours. Again the residue was recovered by centrifugation, and then acid hydrolyzed in $4 \mathrm{ml}$ of dearated $6 \mathrm{~N} \mathrm{HCL}$ for 18 hours. The acid was evaporated by a Speed-Vac (Savant Instruments, Farmingdale, New York), before reconstituting the residue with $500 \mu l$ of water. Each sample was then filtered through a costar Spin-X centrifuge tube filter.

Collagen and Pentosidine Measurement.-Collagen content was determined via spectrophotometric hydroxyproline assay, assuming $14 \%$ of collagen by weight to be hydroxyproline (Maekawa et al. 1970).

Measurement of Ps concentration was accomplished via slight modification of techniques used by Iqbal et al. (1999) and Chaney et al. (2003). Pentosidine concentrations were estimated using a waters 2690 HPLC work station with a waters 494 in-line fluorescence detector (excitation $310 \mathrm{~nm}$, emission $385 \mathrm{~nm}$ ). Elutions off the C-18 column (YMC OCS-AQ $4.6 \times 250 \mathrm{~mm}$ ) were obtained using a linear gradient of 5-28\% acetonitrile in water with .01 M heptafluorobutyric acid from $\odot$ to 35 minutes. The column was cleaned and equilibrated for 18 and 12 minutes respectively. Pentosidine concentrations in duplicate samples spiked with known amounts of Ps also were measured 
to ensure accurate elution time. Quantification of Ps concentration was accomplished using a Ps standard. Integration of peaks was accomplished with Millennium 32 version 3.05.01 software package.

Statistical regression analysis and comparison was completed using SAS software (SAS Institute, Cary, North Carolina). Methods of analysis included Proc GLM, Proc REG, and SAS Proc NLIN.

\section{RESULTS}

The concentration of Ps was found to increase with age in both species of birds.

Ruffed grouse.-Regression analysis of 52 grouse skin samples revealed a curvilinear increase of Ps in ruffed grouse with $y=0.0059 x^{2}+0.1551 x+11.636, R^{2}=0.87$ $(p<0.0001)($ Fig. 1). Grouse data were also fitted with the linear regression line $y=0.8063 x+2.1542, R^{2}=0.80(t=$ 15.20, $p<0.0001)$. For further analytical comparisons, this relationship, having only a modest effect on the coefficient, will be considered for ease of interspecies comparison. No significant sex differences were detected using either analysis. 


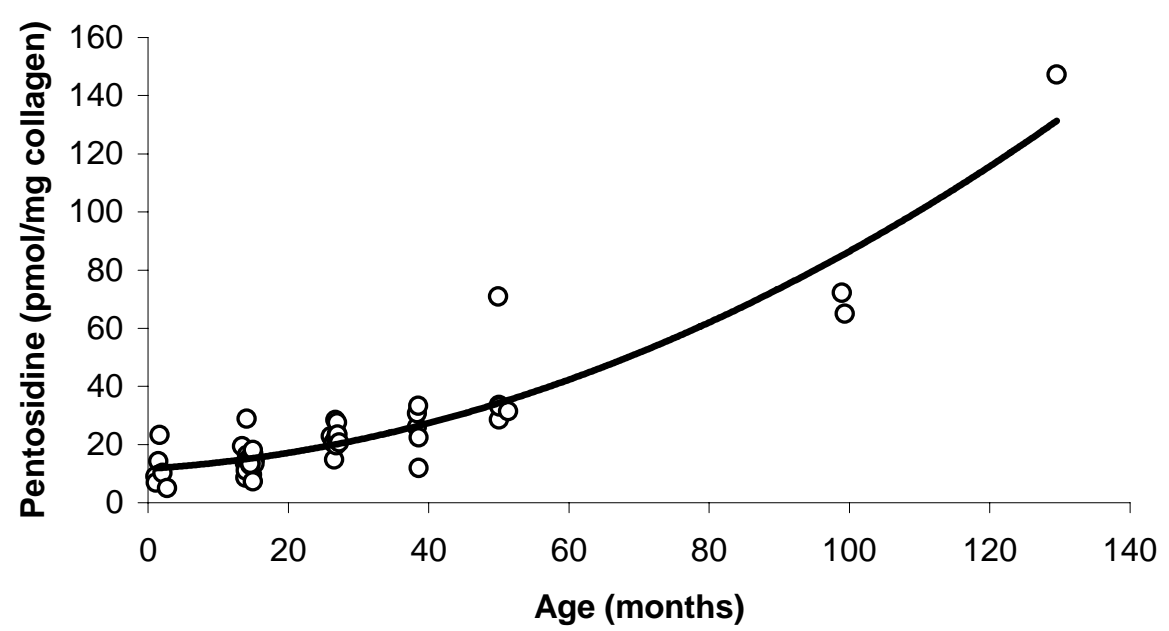

Figure 1. Pentosidine concentration as a function of age in Ruffed grouse.

Double-crested Cormorants. -Pentosidine data from the blind study of 19 cormorants revealed two distinct age groups. This prediction, along with the identification of what appeared to be the 4 oldest and 7 youngest birds, was verified a-posteriori from banding data acquired from the U.S. Geological Survey Bird Banding laboratory. Each of these predictions was independently found to be accurate, at which point age data were provided to our laboratory. Pentosidine concentrations were found to increase linearly with age in cormorants, with $y=0.1914 x+6.6701$, $R^{2}=0.93(t=15.40, P<0.0001)$ as seen in Figure 2. 


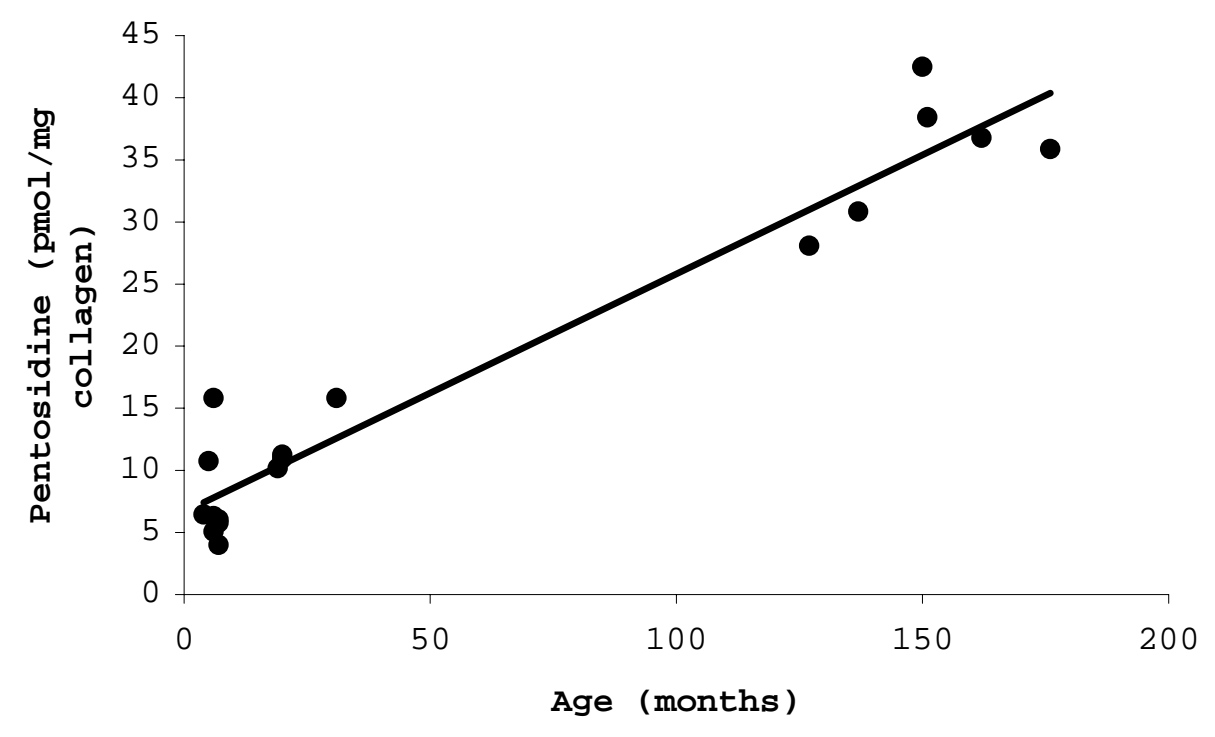

Figure 2. Pentosidine concentration as a function of age in Double-crested cormorants.

Interspecies comparison.-Comparison between species revealed a more rapid increase in Ps concentrations in grouse than in the longer-lived cormorants (Fig. 3). Slope analysis of the regressions confirmed a significant difference in Ps concentrations ( $t=11.03, P<0.0001)$. Additionally, comparison of the regression line from Chaney et al. (2003) revealed a slope very similar to the cormorant data, and different from the grouse data (Fig. $3)$. 


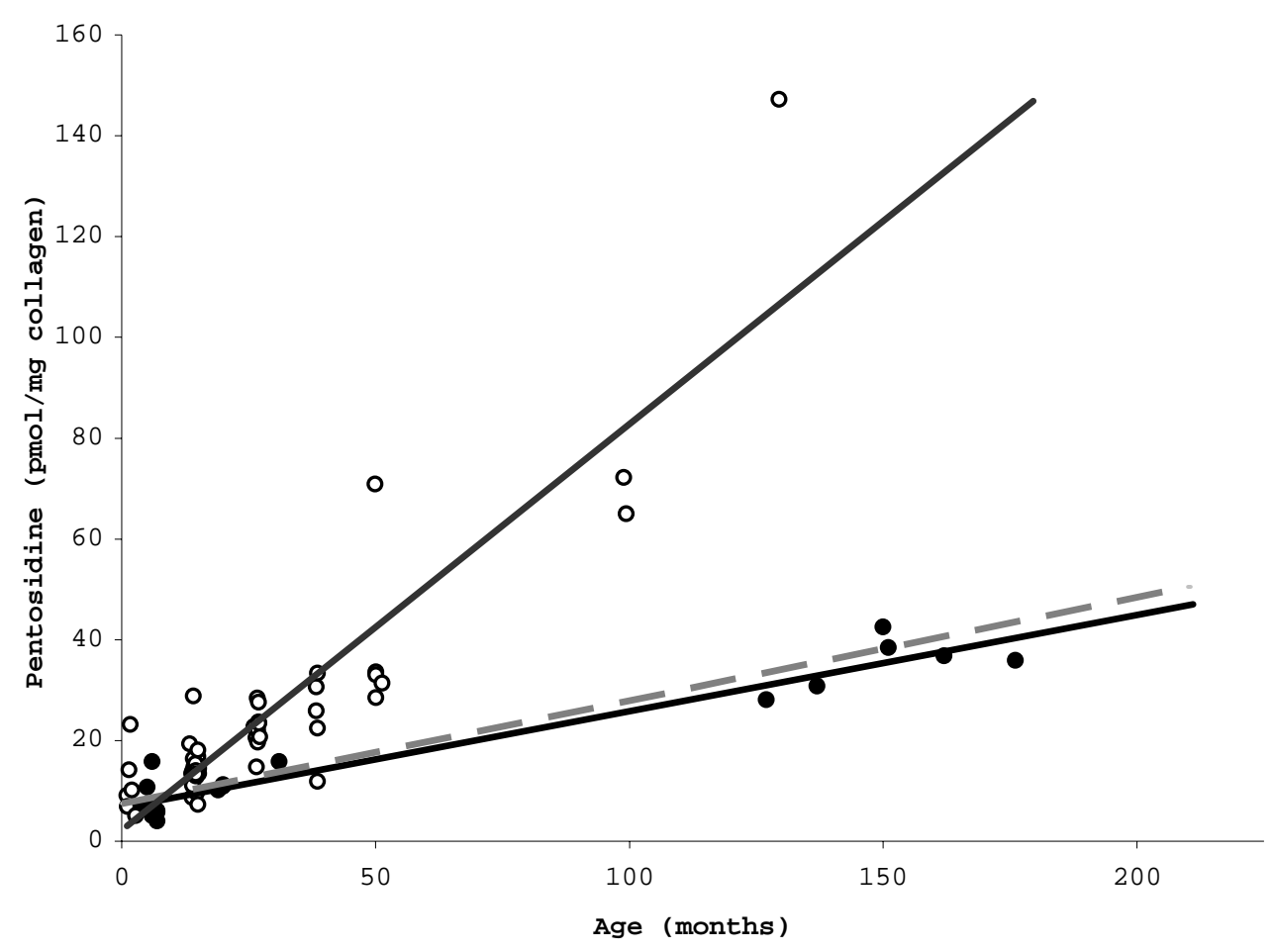

Figure 3. Pentosidine concentration as a function of age in Ruffed grouse (open circles) and Double-crested cormorants (closed circles). Dotted line represents results from Cheney et al. (2003).

\section{DISCUSSION}

In agreement with previous research, Ps accumulation was found to increase with age in both Ruffed grouse and Double-crested cormorants. Ultimately, the goal of this work is to measure Ps, and, using these established relationships, infer the unknown ages of individual birds. 
Data from the blind study of cormorants, which led to an accurate prediction of the oldest, youngest, and similarly aged birds, demonstrates the power of this technique. The ability to categorize birds into age groups alone, even without an established relationship between Ps accumulation and age in an individual species, can contribute enormously to information concerning age related affects on fertility, behavior, and susceptibility to disease.

Although a curvilinear relationship provided the best fit for the grouse data, this relationship depended on Ps concentration in a particularly aged, captive reared grouse which was likely approaching the maximum theoretical lifespan of this species at 10 years of age. More data from grouse of similar age may help confirm this curvilinear relationship. It is possible that as individuals reach extreme geriatric age, the formation of AGEs like Ps accelerate dramatically due to impaired collagen turnover or an increase in oxidative damage leading to age-related physiological malfunctions such as end stage renal disease, as has been suggested in humans (Sell and Monnier 1990).

While a curvilinear relationship between age and Ps concentration was not supported by the cormorant data (fig. 
$2)$, the lack of individuals of intermediate ages may have affected slope estimates for this species. Additional data from "middle-aged" cormorants may indicate a curvilinear relationship more similar to that of the grouse, although the less rapid accumulation of Ps in this longer-lived species would remain.

The distinct difference between Ps accumulation in grouse and cormorants, as illustrated in fig. 3, could be attributed to several factors. First, even in the wild, these two species have vastly different diets and thrive in entirely different habitats. Second, while these Ruffed grouse were raised in captivity and fed ad-libitum, the cormorants had to rely on their foraging abilities in the wild. In mice, dietary restriction has been demonstrated to lead to a decrease in the accumulation of Ps, as well as an increase in longevity (Sell et al. 2000). The difficulty in finding food in the wild when compared to the unlimited access in a captive setting may represent a situation of comparative dietary restriction.

It seems more likely however, that these differences are due to overall longevity of the individual species as suggested in mammals (Sell et al. 1996). Galliformes are a relatively short-lived family of birds, with the oldest wild Ruffed grouse on record being $8^{1 / 2}$ years of age 
(Klimkiewicz and Futcher 1989). Pelecaniformes tend to live much longer, with the oldest wild Double-crested cormorant in North America reaching nearly 18 years (Klimkiewicz and Futcher 1989). Although the underlying mechanisms of the association between Ps accumulation and longevity remain to be established, an inverse relationship between the two has been demonstrated in a variety of mammalian species (Sell et al. 1996).

Whether diet, habitat, longevity, or a combination of the three contribute to these differences in Ps accumulation, it seems unlikely that a generic relationship between the age of individual birds and Ps accumulation will be applicable to all species. However, the striking similarity between the relationship found for the variety of species by Chaney et al. (2003) and the cormorants in this study suggests that some overlap may exist (Fig. 3). Perhaps Ps accumulation between closely related species or species with similar lifespans will coincide enough to make some generalizations. Further investigation into species, family, and genera specific models are needed to confirm this.

\footnotetext{
Although these data present some variation in age estimates, it seems likely that, using Ps accumulation as a guide, we can make accurate age estimates of individual
} 
adult Ruffed grouse and Double-crested cormorants. As we continue to refine the technique, examine the differences between individual species, habitat, and diet, and reduce the size of skin samples necessary for analysis, we will be able to make more precise estimates of the ages of birds.

\section{ACKNOWLEDGEMENTS}

We sincerely acknowledge Elizabeth Falkenstein of West Virginia University for laboratory assistance, Vincent M. Monnier of Case Western University, Cleveland, Ohio for providing Ps standard, George Seidel of West Virginia University for statistical support, and USDA Wildlife Services staff in Mississippi for collection of Doublecrested cormorants.

\section{Literature Cited}

Cerami, A., Vlassara, J., and M. Brownlee. 1987. Glucose and aging. Science 256:90-96.

Chaney, R. C., Blemings, K. P., Bonner, J., and H. Klandorf. 2003. Pentosidine as a measure of chronological age in wild birds. Auk:394-399. 
Iqbal, M., Probert, L.L., and H. Klandorf. 1997. Effect of dietary aminoguanidine on tissue pentosidine and reproductive performance in broiler breeder hens. Poultry Science. 76:1574-1579.

Iqbal, M., Probert, L.L., Al-humadi, N.H., and H. Klandorf. 1999. Protein glycosylation and advanced glycosylation endproducts (AGES): An avian solution. Journal of Gerontology: Biological Science 54:B1-B6.

Klimkiewicz, M. K. and A. G. Futcher. 1989. Longevity records of North American Birds: Supplement I. Journal of Field Ornithology 60(4):469-494.

Maekawa T., Rathinasamy T. K., Altman K. I., and W. F. Forbes. 1970. Changes in collagen with age. The extraction of acid soluble collagens from the skin of mice. Experimental Gerontology 5:177-186.

Sell, D. R. and V. M. Monnier. 1990. End-stage renal disease and diabetes catalyze the formation of a pentose-derived crosslink from aging human collagen. Journal of Clinical Investigation 85:380-384 
Sell, D. R., Lane, M., Johnson, W. A, Masoro, E. J., Mock, 0. B., Reiser, K. M., Fogarty, J. F., Cutler, R. G., Ingram, D.K., Roth, G. S., and V. M. Monnier. 1996. Longevity and the genetic determination of collagen glycoxidation kinetics in mammalian senescence. Proceedings of the National Academy of Science, USA $93: 485-49 \odot$.

Sell, D. R., N. R. Kleinman and V. M. Monnier. 2000. Longitudinal determination of skin collagen glycation and glycoxidation rates predicts early death in C57BL/6NNIA mice. The FASEB Journal 14:145-156.

Terres, J. K. 1980. The Audubon Society Encyclopedia of North American Birds. Alfred A. Knopf, New York, NY. 


\title{
STABILITY OF PENTOSIDINE CONCENTRATIONS IN MUSEUM PREPARED STUDY SKINS
}

\author{
Jesse A. Fallon ${ }^{1}$, William J. Radke ${ }^{2}$, and Hillar Klandorf ${ }^{1}$ \\ ${ }^{1}$ Division of Animal and Veterinary Sciences, West Virginia \\ University, Morgantown, West Virginia 26506-6108, USA \\ hillar.klandorf@mail.wvu.edu \\ ${ }^{2}$ University of Central Oklahoma, Edmond, OK, 73034, USA
}


Abstract.- Accumulation of the advanced glycation endproduct pentosidine (Ps) in skin collagen is strongly correlated with the age of adult birds, allowing age estimates to be made without the use of banding data. The current investigation advances the use of this technique to determine the stability of Ps in museum prepared study skins. Skin samples from six Ruffed grouse prepared as study skins were taken at three month intervals over the course of one year. The data revealed no significant variation in Ps concentrations within individual birds, indicating that Ps is stable in study skins for at least twelve months. These data suggest that inferences concerning age may be made on similarly prepared specimens from collections around the world. Additionally, significant variations in Ps concentrations with respect to 6 different body locations in skin collagen of six Ruffed grouse were uncovered. This suggests that care and consistency should be employed when excising skin for Ps measurement and age estimation in birds.

Most species of birds exhibit no external morphological indicators of age once the threshold into adulthood has been crossed. The inherent value of age information and the limitations of banding data have led to 
the development of a new technique for estimating the age of adult birds. It uses the accumulation of the protein crosslink pentosidine (Ps) as an indicator, or biomarker, for biological age (Sell et al. 1996; Iqbal et al. 1999; Chaney et al. 2003).

Pentosidine results from the modification of proteins by reducing sugars in a processes termed glycoxidation (Baynes 1991). An unavoidable outcome of the aging process, Ps is a fluorescent, irreversible compound that is cumulative in vivo. These facts make it a reliable, readily measured biomarker of aging. Accumulation of Ps has been significantly correlated to chronological age in mammals, and more recently birds (Sell et al. 1996; Iqbal et al. 1999). Chaney et al. (2003) described a linear correlation between Ps accumulation in skin collagen and chronological age in adult birds; i.e., Ps accumulates in a predictable manner. This work suggests that by measuring the concentration of Ps and using this correlation, an accurate estimate of chronological age of non-banded birds can be made (Chaney et al. 2003).

Currently, age estimation in birds using this technique has been gathered only from recently deceased specimens. It may be possible, however, to retrieve age information from another source. Ornithologists have long 
been collecting birds and preparing them as museum specimens by removing and drying the skin (Winker 2000). These skins provide valuable information about morphological measurements and identification techniques for individual species (Baldwin et al. 1931). This investigation advances the potential of Ps as an estimator for age in museum prepared study skins. It examines the effect of time on the stability of Ps concentrations in Ruffed grouse (Bonasa umbellus) prepared as study skins, and takes multiple samples from individual birds. Stability of Ps would allow for age estimation at the time of death of specimens similarly prepared.

Consistently different levels of Ps concentration between fresh samples taken from foot webbing and breast skin have previously been noted in California gulls (Larus californicus) (Chaney et al. 2003). Because of these results, and because in this study multiple samples have been taken from individual study skins, we have examined the variation of Ps concentration between different body locations of individual grouse.

\section{MATERials AND Methods}

Tissue Procurement and Study Skin Preparation.-Initial Ruffed grouse skin samples were obtained at necropsy from 
West Virginia University's captive colony immediately after death. Approximately $25 \mathrm{~g}$ of skin was removed from the breast of six male Ruffed grouse of known ages, two from each of three different age groups; 2, 4 and 8 years old. For the duration of the study (up to 12 months depending on what month the sample was taken) and prior to processing, samples were stored at $-80^{\circ} \mathrm{C}$.

After excising initial skin samples and making appropriate individual measurements (Baldwin et al. 1931), each bird was prepared as described by winker (2000) with a few modifications. Skin was carefully removed from the six birds, cleaned of adipose and muscle tissue, and treated with hydrous sodium borate (Borax). The skins were then sewed onto cotton "bodies" attached to $3 \mathrm{~cm}$ dowel rods for stability. These skins were allowed to air dry in a well ventilated location, and were rotated every third day to encourage even drying.

Two $\mathrm{cm}^{2}$ samples were removed from skin around the breast of the specimens every three months over the course of one year, for a total of five chronological samples from each bird. After removal, samples were scraped and cleaned of feather shafts, adipose tissue and excess Borax. Individual skin samples were stored at $-80^{\circ} \mathrm{C}$ for the duration of the study. Sample processing and PS 
measurements as described below began only after all samples were collected.

In a separate investigation, skin samples were taken from 6 different body locations of 6 male Ruffed grouse of known ages. These locations included the breast, abdomen, lower back, upper back, right wing, and right thigh. Samples were taken at necropsy immediately after death, cleaned of feather shafts, adipose tissue, and circulatory vessels and processed and assayed together as described below.

Sample Processing.-Skin samples were further prepared as described by Iqbal et al. (1997) and Chaney et al. (2003). Forty mg of the remaining connective tissues were minced and then delipidated in a 2:1 chloroform/methanol solution for 18 hours. Following delipidation, the residue was recovered by centrifugation and placed in $4 \mathrm{ml}$ of $1: 1$ water/methanol solution for 2 hours. The collagen residue was again recovered by centrifugation, and then acid hydrolyzed in $4 \mathrm{ml}$ of dearated $6 \mathrm{~N} \mathrm{HCL}$ for 18 hours. The acid was evaporated by a Speed-Vac (Savant Instruments, Farmingdale, New York), and each sample was reconstituted with $500 \mu l$ of water. Each sample was then filtered through a Costar Spin-X centrifuge tube filter. 
Collagen and Pentosidine Measurement.-Collagen content of the remaining solutions was determined via spectrophotometric hydroxyproline assay in duplicates, assuming $14 \%$ of collagen by weight to be hydroxyproline (Maekawa et al., 1970).

Measurement of Ps concentration was accomplished via slight modification of techniques used by Iqbal et al. (1999) and Chaney et al. (2003). Pentosidine concentrations were estimated using a waters 2690 HPLC work station with a waters 494 in-line fluorescence detector (excitation $310 \mathrm{~nm}$, emission $385 \mathrm{~nm}$ ). Elutions off the C-18 column (YMC OCS-AQ $4.6 \times 250 \mathrm{~mm}$ ) were obtained using a linear gradient of $5-28 \%$ acetonitrile in water with .01 M heptafluorobutyric acid from $\odot$ to 35 minutes. The column was cleaned and equilibrated for 18 and 12 minutes respectively. Pentosidine concentrations in duplicate samples spiked with known amounts of Ps also were measured to ensure accurate elution time. Quantification of Ps concentration was accomplished using a Ps standard. Integration of peaks was accomplished with Millennium 32 version 3.05.01 software package. 
Statistical Analysis.-Study skin data were analyzed using a random complete block design with months after study skin preparation serving as treatments within individual birds. Fisher'S LSD test also was used to examine differences between individual birds and age groups.

Random complete block design and Fisher'S LSD analysis were implemented to assess differences in Ps concentrations between 6 different body locations (treatments) of fresh samples from 6 Ruffed grouse of known ages (blocks). All data were analyzed using SAS statistical software (SAS Institute, Cary, North Carolina).

\section{RESULTS}

Study Skins.-Pentosidine concentrations measured in pmol/mg collagen remained stable over time in the six Ruffed grouse study skins. Randomized complete block analysis revealed no significant difference $(F=1.49, P>0.24)$ in $P S$ concentrations between samples taken at three month intervals, over the course of one year, within individual birds and individual age groups. Fisher's LSD $(t=2.09)$ uncovered no significant difference within individual age groups. The eight year old age group had significantly higher Ps concentrations than the four and two year old groups. Similarly the four year old group had 
significantly higher Ps concentrations than the two year old group.

Mean and standard deviations for each bird are listed in Table I. Data points, mean $[\mathrm{Ps}] / \mathrm{mg}$ collagen, and 95\% confidence intervals for each age group are shown in Figure 1. No trend towards a decline or increase in Ps with time after study skin preparation was noted.

\begin{tabular}{||cc||}
\hline \multicolumn{3}{|c|}{ Table I. } \\
Pentosidine stability in study skins \\
Means and standard deviations of pentosidine \\
concentrations in 2, 4, and 8 year old Ruffed grouse \\
different letters indicate significant difference
\end{tabular}




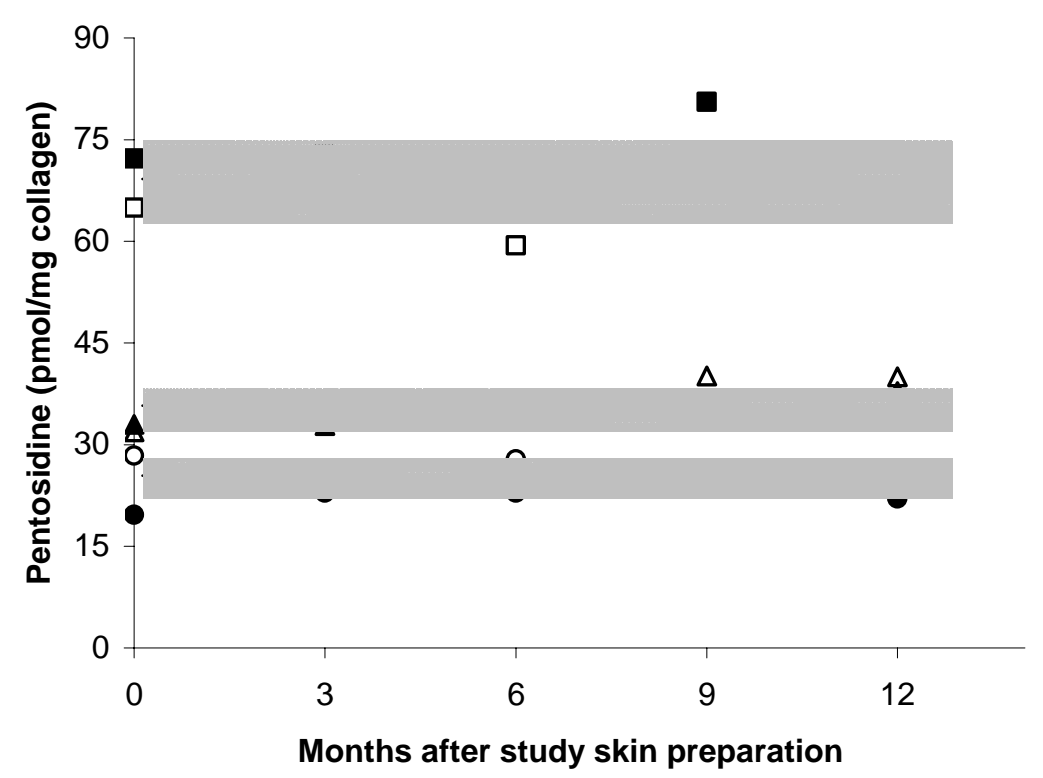

Figure 1. Mean and 95\% confidence intervals of pentosidine concentration as a function of time after study skin preparation in 2 year old (circles), 4 year old (triangles), and 8 year old (squares) Ruffed grouse.

Variability Between Body Locations. -Random complete block analysis revealed significant differences between skin taken from different body locations $(F=4.94, P<.01)$ of six grouse. Fisher's LSD test $(t=2.06)$ confirmed skin taken from the thigh and wing area to have significantly higher concentrations of Ps then skin taken from the breast. Tissue taken from the abdomen, and the upper and lower back did not have significantly different Ps concentrations than tissue taken from the breast (table II). 


\begin{tabular}{|c|c|}
\hline \multicolumn{3}{|c|}{ Table II. } \\
Pentosidine variation between body locations \\
Mean pentosidine concentrations of skin samples taken \\
from different body locations of Ruffed grouse \\
*indicates significant difference from skin taken from the breast \\
\hline \\
Body Location & Mean pentosidine concentration \\
& $($ pmol/mg collagen) \\
Breast & 29.178 \\
Abdomen & 27.543 \\
Lower Back & 32.564 \\
Upper Back & 32.017 \\
Thigh & $34.795^{\star}$ \\
Wing & $38.821^{*}$ \\
\hline
\end{tabular}

\section{DISCUSSION}

In agreement with previous studies, statistical analysis revealed Ps concentrations to be proportionately higher in 8 year old birds than in 4 year old birds, and similarly in 4 year olds than in 2 year old birds Table I). Moreover, these data suggest that Ps remains stable over time in museum prepared study skins, at least for the duration of the sampling period of one year. Most importantly, there was no consistent trend of Ps over time in any of the samples (fig. 1).

Advanced glycation endproducts have been demonstrated to have half-lives of 117 years in cartilage collagen and 15 years in skin collagen of humans (Verzijl et al., 2000). These half-lives were determined from collagen turnover in vivo. Providing proper preservation and storage, and 
barring collagen degradation, Ps is likely to survive much longer in study skins. If Ps continues to maintain its stability for extended periods of time, then the prospect of obtaining samples from an enormous number of museum specimens becomes available. Indeed, by taking only a small skin sample, the ability to retrieve age information from species that have undergone extinction becomes conceivable. Specimens of Ivory-billed woodpeckers (Campephilus principalis), Carolina parakeets(Conuropsis carolinensis), and Passenger pigeons (Ectopistes migratorius) could provide data on the age of the animal at the time of collection.

Variations, demonstrated by standard deviations (Table I), in Ps concentrations within individual birds may possibly be due to imperfections in the technique. It seems more likely, however, that Ps concentrations in skin collagen differ between certain locations of body due to varying vascularlization, relative body temperature, rates of collagen turnover, or concentrations of tissue antioxidants. While every effort was made to obtain samples from the same general area around the breast, initial preservation and previous sample removals made this a challenging undertaking, and some samples included tissue from the abdominal region. 
The variation in Ps concentrations found between different body locations in fresh samples supports this. Fortunately, the consistent differences shown here indicate that, with enough samples, perhaps compensations for different body locations may be made. In the meantime, this preliminary research implies that great care must be taken when excising skin for age estimation in both recently deceased birds and study skins.

While it is undetermined whether Ps concentrations will remain stable for more extended periods of time in museum prepared study skins, this investigation suggests relative stability for the duration of one year (Fig. 1). These data provide experimental evidence that Ps accumulation cannot only suggest age information from live or recently deceased birds, but, providing appropriate preservation, also from individuals that have expired and been prepared as study skins.

Museum specimens are admired by visitors the world over, and study skins serve as a valuable tool for ornithologists to learn identification diagnostic techniques, gather useful morphology measurements, and even extract genetic information (Winker 2000; Baldwin et al. 1931; Payne 2003). The stability of the biomarker Ps demonstrated here is unique, and these data suggest that 
avian study skins can now be evaluated for age estimates as well, at least for the duration of one year. Further studies are needed to determine the long-term stability of Ps in museum specimens.

ACKNOWLEDGMENTS

We sincerely acknowledge Elizabeth Falkenstein of West Virginia University for laboratory assistance, R. L. Cochrane of West Virginia University for providing grouse tissue, Vincent M. Monnier of Case Western University, Cleveland, Ohio for providing Ps standard, and George Seidel of West Virginia University's Department of Statistics for statistical support. 


\section{Literature Cited}

Baldwin, S.P., Oberholser, H.C., and L. G. Worley. 1931. Measurements of birds. Scientific Publication Cleveland Museum of Natural History II.

Baynes, J. W. 1991. Role of oxidative stress in development of complications in diabetes. Diabetes 40:405-412.

Cerami, A., Vlassara, J., and M. Brownlee. 1987. Glucose and aging. Science 256:90-96.

Chaney, R. C., Blemings, K. P., Bonner, J., and H. Klandorf. 2003. Pentosidine as a measure of chronological age in wild birds. Auk:394-399.

Fayle, S. E. and J.A. Gerrard. 2002. Pages 1-8 in The Maillard Reaction (P. S. Beldon, Ed.) Royal Society of Chemistry, Great Britain.

Greenberg, R. E., S. L. Etter, and W. L. Anderson. 1972. Evaluation of proximal primary feather criteria for aging wild pheasants. Journal Wildlife Management $36: 700-705$. 
Iqbal, M., Probert, L.L., Al-humadi, N.H., and H. Klandorf. 1999. Protein glycosylation and advanced glycosylation endproducts (AGES): An avian solution. Journal of Gerontology: Biological Sciences 54:B1-B6.

Iqbal, M., Probert, L.L., and H. Klandorf. 1997. Effect of dietary aminoguanidine on tissue pentosidine and reproductive performance in broiler breeder hens. Poultry Science 76:1574-1579.

Johnsen, A., Lifjeld, J. T., and C. Krokene. 2003. AgeRelated Variation in Mate-Guarding Intensity in the Bluethroat (Luscinia svecica). Ethology 109:147- 158.

Kohn, R. R., Cerami, A., and V. M. Monnier V.M. 1984. Collagen aging in vitro by non-enzymatic glycosylation and browning. Diabetes. 33:57-59.

Maekawa T., Rathinasamy T. K., Altman K. I., and W. F. Forbes. 1970. Changes in collagen with age. The extraction of acid soluble collagens from the skin of mice. Experimental Gerontology 5:177-186. 
Maransky, B. P. and K. L. Bildstein. 2002. Follow Your Elders: Age-related Differences in the Migration Behavior of Broad-winged Hawks at Hawk Mountain Sanctuary, Pennsylvania. The Wilson Bulletin 113:350353.

Monnier V.M., and Cerami A. 1983. Detection of nonenzymatic browning products in the human lens. Biochemica Biophysical Acta. 760:97-103.

Monnier V. M., Kohn R. R., and A. Cerami A. 1984. Accelerated age-related browning of human collagen in diabetes mellitus. Proceedings of the National Academy of Sciences of the United States of America $81: 583-587$.

Payne, R.B. and M.D. Sorenson. 2003. Museum collections as sources of genetic data. Bird Collections in Europe: the Challenge of Mutual Cooperation. Bonner Zoologische Beiträge 51:97-104.

Pickering, S.P.C. 1988. Attendance patterns and behaviour in relation to experience and pair-bond formation in 
the Wandering Albatross Diomedea exulans at South Georgia. Ibis 131: 183-195.

Sell, D.R., and Monnier, V.M. 1989. Structure elucidation of a senescence cross-link from human extracellular matrix. Implication of pentoses in the aging process. Journal of Biological Chemistry 264:21597-21602.

Sell, D. R., Lane, M., Johnson, W. A, Masoro, E. J., Mock, 0. B., Reiser, K. M., Fogarty, J. F., Cutler, R. G., Ingram, D.K., Roth, G. S., and V. M. Monnier. 1996. Longevity and the genetic determination of collagen glycoxidation kinetics in mammalian senescence. Proceedings of the National Academy of Sciences, USA $93: 485-490$.

Smith, C. M., Cooke, F., Robertson,G. J., Goudie, R. I., and W. S. Boyd. 2000. Long-term pair bonds in Harlequin ducks. The Condor 102:201-205. 
Verzijl., N., Degroot, J., Thorpe, S.R., Bank, R.A., Shaw J.N., Lyons, T.J., Bijlsma, J.W.J., Lafeber, F.P.J., Baynes, J.W., and J. M. TeKoppele. 2000. Effect of collagen turnover on the accumulation of advanced glycation end products. Journal of Biological Chemistry 275:39027-39031.

Winker, K. 2000. Obtaining, preserving, and preparing bird specimens. Journal of Field Ornithology 71:250-297. 


\section{Conclusions}

This research confirms the use of a powerful new tool for estimating the age of adult birds. It demonstrates that the advanced glycation endproduct pentosidine is an accurate biomarker of chronological age in birds. Interspecies examination uncovered a more rapid accumulation of pentosidine in the granivorous, short lived species, Ruffed grouse than the piscivorous, long-lived species, Double-crested cormorants, supporting previous evidence of an inverse relationship between glycoxidation rate and maximum life expectancy. Additionally, the blind study of Double-crested cormorants verifies, even without previous pentosidine data, that this technique can be used to gather useful age information.

The data herein also suggest that age information can be collected from museum prepared study skins, as pentosidine was shown to remain stable in study skins for at least the duration of one year. If the crosslink continues to remain stable, this opens the door to an enormous amount of skins, potentially from birds that have gone extinct, that could be used to gather age information. As with most scientific research, this work brings about as many questions as it does answers. Will diet and 
habitat be found to impact Ps accumulation? Will maximum lifespan be the determining factor? Can this technique be performed on live birds in the wild without endangering them? Will pentosidine continue to remain stable over extended periods of time in study skins? As this project continues, these questions are just a few of the possible lines of inquiry. Hopefully, this current work will aid in our understanding of the population demographics of birds, as well as increase our awareness of birds as animal models for aging, thereby contributing to our understanding of the aging process in general.

It seems remarkable that an innate biological process so entwined in the life of all multicellular organisms can continue to confound our most diligent efforts. However, as determined scientists, we will continue to plod along, working at the complex knot that is the mystery of aging. Perhaps the resilience of the problem, along with its profound implication on the lives of us all, is what draws us out, beckons us to pull this loop, to loosen that kink. While the ultimate impact of this development in age estimation of birds may be small, it is not insignificant, and hopefully, is a step in the right direction. 


\section{Appendix A: Ps concentrations in Ruffed grouse}

\begin{tabular}{|c|c|c|c|}
\hline Bird \# & Age (days) & Sex & Ps (pmol/mg collagen) \\
\hline $99-2$ & 51 & $f$ & 23.21240652 \\
\hline 01-6 Blue & 63 & $f$ & 10.1820174 \\
\hline 91-1 & 3943 & $\mathrm{~m}$ & 147.2210874 \\
\hline 01-46 green & 45 & $f$ & 14.16094516 \\
\hline $99-29$ & 409 & $f$ & 19.31780863 \\
\hline 01-13 yellow & 84 & $f$ & 5.069414607 \\
\hline $01-43$ yellow & 35 & $f$ & 6.858875355 \\
\hline $99-13$ & 33 & $f$ & 9.094951039 \\
\hline $98-33$ & 1524 & $\mathrm{~m}$ & 28.52789965 \\
\hline $00-43$ & 808 & $f$ & 14.75203462 \\
\hline $98-35$ & 1524 & $\mathrm{~m}$ & 33.60901179 \\
\hline $94-53$ & 3011 & $\mathrm{~m}$ & 72.20836828 \\
\hline $00-31$ & 815 & $\mathrm{~m}$ & 22.07057855 \\
\hline $00-80$ & 805 & $f$ & 20.55311792 \\
\hline $00-06$ & 829 & $\mathrm{~m}$ & 20.71988628 \\
\hline $00-74$ & 794 & $f$ & 22.77633673 \\
\hline $00-14$ & 823 & $\mathrm{~m}$ & 23.40093885 \\
\hline $99-26$ & 1167 & $\mathrm{~m}$ & 30.65953818 \\
\hline 01-06 yellow & 437 & $f$ & 13.00828168 \\
\hline $99-12$ & 1174 & $f$ & 22.4425849 \\
\hline $94-93$ & 3024 & $\mathrm{~m}$ & 64.94534419 \\
\hline 01-15 green & 451 & $f$ & 9.554317173 \\
\hline 01-13 blue & 424 & $\mathrm{~m}$ & 11.02662448 \\
\hline $99-27$ & 1167 & $f$ & 25.92517856 \\
\hline $98-01$ & 1563 & $\mathrm{~m}$ & 31.36841482 \\
\hline $98-30$ & 1525 & $\mathrm{~m}$ & 33.02055565 \\
\hline 01-15 blue & 423 & $f$ & 8.658886279 \\
\hline 01-12 blue & 429 & $\mathrm{~m}$ & 28.80639994 \\
\hline 01-36 green & 444 & $\mathrm{~m}$ & 14.04217897 \\
\hline $00-21$ & 816 & $\mathrm{~m}$ & 19.64351154 \\
\hline $99-18$ & 1174 & $\mathrm{~m}$ & 11.91743848 \\
\hline 01-24 orange & 450 & $?$ & 13.43833861 \\
\hline 01-28 green & 456 & $\mathrm{~m}$ & 18.12433242 \\
\hline $00-28$ & 821 & $\mathrm{~m}$ & 23.64659186 \\
\hline 01-41 green & 448 & $f$ & 12.78061835 \\
\hline 01-10 green & 456 & $\mathrm{~m}$ & 7.306903243 \\
\hline 01-1 yellow & 443 & $\mathrm{~m}$ & 15.41568936 \\
\hline 01-74 yellow & 463 & $f$ & 14.96940912 \\
\hline 01-80 yellow & 463 & $f$ & 14.45168527 \\
\hline 01-33 yellow & 436 & $\mathrm{~m}$ & 14.90692115 \\
\hline 01-34 blue & 445 & $\mathrm{~m}$ & 12.90489785 \\
\hline 01-73 yellow & 463 & $f$ & 13.3980767 \\
\hline 01-37 green & 449 & $f$ & 13.9021124 \\
\hline
\end{tabular}




\section{Ps concentrations in Ruffed grouse (continued)}

\begin{tabular}{|c|c|c|c|}
\multicolumn{1}{c}{ Bird \# } & \multicolumn{1}{c}{ Age (days) } & Sex & Ps (pmol/mg collagen) \\
\hline $01-23$ blue & 428 & $\mathrm{f}$ & 14.11459966 \\
\hline $01-2$ green & 457 & $\mathrm{f}$ & 16.78510306 \\
\hline $00-22$ & 821 & $\mathrm{~m}$ & 27.60021967 \\
\hline $98-41$ & 1519 & $\mathrm{~m}$ & 51.06680068 \\
\hline $01-29$ blue & 445 & $\mathrm{~m}$ & 13.35087993 \\
\hline $01-27$ blue & 421 & $\mathrm{f}$ & 13.46687739 \\
\hline $01-20$ yellow & 442 & $\mathrm{~m}$ & 13.14337017 \\
\hline $99-22$ & 1173 & $\mathrm{~m}$ & 33.3124474 \\
\hline $01-37$ yellow & 430 & $\mathrm{~m}$ & 16.37192705 \\
\hline $00-34$ & 814 & $\mathrm{~m}$ & 28.40609898 \\
\hline
\end{tabular}

\section{Appendix B: Ps Concentrations in Double-crested cormorants}

\begin{tabular}{|c|c|c|c|}
\hline Bird \# & Age (months) & sex & Ps (pmol/mg collagen) \\
\hline $878-97644$ & 7 & $\mathrm{~m}$ & 3.995 \\
\hline 0978-77497 & 6 & $\mathrm{~m}$ & 5.075 \\
\hline $878-97738$ & 7 & $\mathrm{~m}$ & 5.772 \\
\hline $868-94282$ & 7 & $\mathrm{~m}$ & 6.032 \\
\hline $878-97780$ & 6 & $\mathrm{~m}$ & 6.221 \\
\hline 0978-76965 & 6 & $\mathrm{~m}$ & 6.325 \\
\hline 888-19208 & 4 & $\mathrm{~m}$ & 6.456 \\
\hline $878-96952$ & 19 & $?$ & 10.192 \\
\hline $878-10336$ & 5 & $\mathrm{~m}$ & 10.762 \\
\hline 638-01573 & 20 & $f$ & 10.934 \\
\hline $878-47605$ & 20 & $?$ & 11.252 \\
\hline 0978-76887 & 6 & $?$ & 15.804 \\
\hline 789-18655 & 31 & $?$ & 15.833 \\
\hline $1247-55297$ & 127 & $\mathrm{~m}$ & 28.062 \\
\hline $1247-28951$ & 137 & $\mathrm{~m}$ & 30.827 \\
\hline $937-62746$ & 176 & $\mathrm{~m}$ & 35.864 \\
\hline 2358-15299 & 162 & $\mathrm{~m}$ & 36.759 \\
\hline $1227-56154$ & 151 & $?$ & 38.425 \\
\hline $1227-56046$ & 150 & $\mathrm{~m}$ & 42.495 \\
\hline
\end{tabular}




\section{Appendix C: Ps concentrations at different sampling locations around body}

\begin{tabular}{|c|c|c|c|c|}
\hline Bird \# & Age (days) & Sex & Body Location & Ps (pmol/mg collagen) \\
\hline \multirow[t]{6}{*}{ 01-28 green } & 456 & $\mathrm{~m}$ & Breast & 17.16805931 \\
\hline & & & Abdomen & 12.22843653 \\
\hline & & & Thigh & 13.8883889 \\
\hline & & & Lower Back & 15.59995709 \\
\hline & & & Upper Back & 14.75206267 \\
\hline & & & Wing & 13.27838059 \\
\hline \multirow[t]{6}{*}{$00-14$} & 823 & $\mathrm{~m}$ & Breast & 25.96709472 \\
\hline & & & Abdomen & 23.48110651 \\
\hline & & & Thigh & 24.71840814 \\
\hline & & & Lower Back & 28.32321958 \\
\hline & & & Upper Back & 29.35714804 \\
\hline & & & Wing & 32.34793262 \\
\hline \multirow[t]{6}{*}{$99-22$} & 1173 & $\mathrm{~m}$ & Breast & 31.2395585 \\
\hline & & & Abdomen & 29.95866466 \\
\hline & & & Thigh & 43.99255228 \\
\hline & & & Lower Back & 33.00035449 \\
\hline & & & Upper Back & 33.18398572 \\
\hline & & & Wing & 35.50777821 \\
\hline \multirow[t]{6}{*}{$99-18$} & 1174 & $\mathrm{~m}$ & Breast & 32.98081229 \\
\hline & & & Abdomen & 27.23330021 \\
\hline & & & Thigh & 56.00490695 \\
\hline & & & Lower Back & 31.6982323 \\
\hline & & & Upper Back & 36.18550146 \\
\hline & & & Wing & 38.1353361 \\
\hline \multirow[t]{6}{*}{$98-35$} & 1524 & $\mathrm{~m}$ & Breast & 36.80325661 \\
\hline & & & Abdomen & 37.87481562 \\
\hline & & & Thigh & 49.7166089 \\
\hline & & & Lower Back & 47.57840232 \\
\hline & & & Upper Back & 42.12028764 \\
\hline & & & Wing & 45.87374421 \\
\hline \multirow[t]{6}{*}{$98-1$} & 1563 & $\mathrm{~m}$ & Breast & 30.90955642 \\
\hline & & & Abdomen & 34.48299507 \\
\hline & & & Thigh & 44.60750625 \\
\hline & & & Lower Back & 39.18399574 \\
\hline & & & Upper Back & 36.50039751 \\
\hline & & & Wing & 43.62827515 \\
\hline
\end{tabular}




\section{Appendix D: Stability of Ps in Study Skins}

\begin{tabular}{|c|c|c|c|c|}
\hline Bird & Age (months) & Sex & Age (days) & Ps (pmol/mg collagen) \\
\hline \multirow[t]{5}{*}{$98-30$} & 48 & $\mathrm{~m}$ & 0 (Before Preparation) & 33.02055565 \\
\hline & & & 3 Months & 32.78458662 \\
\hline & & & 6 Months & 34.9598049 \\
\hline & & & 9 Months & 35.19847463 \\
\hline & & & 12 months & 37.85400854 \\
\hline \multirow[t]{5}{*}{$94-53$} & 96 & $\mathrm{~m}$ & 0 (Before Preparation) & 72.20836828 \\
\hline & & & 3 Months & 66.78366852 \\
\hline & & & 6 Months & 68.5326413 \\
\hline & & & 9 Months & 80.59465554 \\
\hline & & & 12 months & 66.53265444 \\
\hline \multirow[t]{5}{*}{$00-21$} & 24 & $\mathrm{~m}$ & 0 (Before Preparation) & 19.64351154 \\
\hline & & & 3 Months & 22.91367152 \\
\hline & & & 6 Months & 22.91367152 \\
\hline & & & 9 Months & 25.13508429 \\
\hline & & & 12 months & 22.04518206 \\
\hline \multirow[t]{5}{*}{$98-33$} & 48 & $\mathrm{~m}$ & 0 (Before Preparation) & 31.86523545 \\
\hline & & & 3 Months & 33.44893031 \\
\hline & & & 6 Months & 34.87625928 \\
\hline & & & 9 Months & 40.12600245 \\
\hline & & & 12 months & 40.03311143 \\
\hline \multirow[t]{5}{*}{$00-34$} & 24 & $\mathrm{~m}$ & 0 (Before Preparation) & 28.40609898 \\
\hline & & & 3 Months & 26.06809879 \\
\hline & & & 6 Months & 27.82159414 \\
\hline & & & 9 Months & 26.40104245 \\
\hline & & & 12 months & 24.61213105 \\
\hline \multirow[t]{5}{*}{$94-93$} & 96 & $\mathrm{~m}$ & 0 (Before Preparation) & 64.94534419 \\
\hline & & & 3 Months & 73.17937634 \\
\hline & & & 6 Months & 59.4208736 \\
\hline & & & 9 Months & 67.98261325 \\
\hline & & & 12 months & 65.89652443 \\
\hline
\end{tabular}




\section{Literature Cited}

Amadori, M. 1931. Condensation products of glucose with ptoluidine. Atti della Accademia Nazionale dei Lincei, Classe di Scienze Fisiche, Matematiche e Naturali, Rendiconti 13:72-77.

Barja, B. 2004. Mammalian and bird aging, oxygen radicals, and restricted feeding. Pages 173-189 in Model Systems in Aging ( $T$. Nystrom, Ed.) Springer-Verlag Berlin Heidelberg, New York.

Baker, G. T., III and R. L. Sprott. 1988. Biomarkers of aging. Experimental Gerontology 23:223-239.

Baldwin, S.P., Oberholser, H.C., and L. G. Worley. 1931. Measurements of birds. Scientific Publication Cleveland Museum of Natural History II.

Baynes, J. W. 1991. Role of oxidative stress in development of complications in diabetes. Diabetes 40:405-412. 
Bellmunt, M. J. M Portero, R. Pamplona, L. Cosso, P. Odetti, and J. Prat. 1995. Evidence for the Maillard reaction in rat lung collagen and its relationship with solubility and age. Biochimica et Biophysica Acta $1272: 53-60$.

Beuchat, C.A., and C.R. Chong. 1998. Hyperglycemia and its consequences for hemoglobin glycation. Comparative Biochemistry and Physiology. A120:409-416

Bierhaus A., Chevion S., Chevion M., Hofmann M., Quehenberger P., Illmer T., Luther T., Berentshtein E., Tritschler H., Muller M., Wahl P., Ziegler R., P. and P. Nawroth. 1997. Advanced glycation end productinduced activation of NF-kappaB is suppressed by alpha-lipoic acid in cultured endothelial cells. Diabetes $46: 1481-90$.

Bucala, R. and A. Cerami. 1992. Advanced glycosylation: chemistry, biology, and implications for diabetes and aging. Advances in Pharmacology 23:1-34. 
Bunn, H. F., and P.J. Higgins. 1981. Reaction of monosaccharides with proteins:possible evolutionary significance. Science 213:222-224.

Cerami, A., Vlassara, J., and M. Brownlee. 1987. Glucose and aging. Science 256:90-96.

Chaney, R. C., Blemings, K. P., Bonner, J. and H. Klandorf. 2003. Pentosidine as a measure of chronological age in wild birds. Auk:394-399.

Del Maestro, R. F. 1980. An approach to free radicals in medicine and biology. Acta Physiologica Scandinavica, Supplementum 492:153-168.

Dyer D. G., J. A. Dunn, S. R. Thorpe, K. E. Bailie, T. J. Lyons, D. R. McCance, and J. W. Baynes. 1993. Accumulation of Maillard reaction products in skin collagen in diabetes and aging. Journal of Clinical Investigation 91:2463-2469.

Fayle, S. E. and J.A. Gerrard. 2002. Pages 1-8 in The Maillard Reaction (P. S. Beldon, Ed.) Royal Society of Chemistry, Great Britain. 
Fisher, H.I. 1975. Longevity of the Laysan albatross, Diomedia immutabius. Bird Banding 46:1-6.

Greenberg, R. E., S. L. Etter, and W. L. Andersson. 1972. Evaluation of proximal primary feather criteria for aging wild pheasants. Journal Wildlife Management $36: 700-705$.

Hayase F, R. H. Nagaraj, S. Miyata, F. G. Njoroge, and V. M. Monnier. 1989. Aging of proteins: immunological detection of a glucose-derived pyrrole formed during maillard reaction in vivo. Journal of Biological Chemistry 264:3758-3764.

Heyns, K., Paulsen, H., Eichstedt, R., and M. Rolle. 1957. The formation of 2-aminoaldoses by rearrangement of ketosylamines. Chemische Berichte 90:2039-49.

Holmes, J. D., and S. N Austad. 1995. Birds as animal models for the comparative biology: prospectus. Journal of Gerontology: Biological Science. 50A:B59B66. 
Holmes, D.J., R. Fluckiger, and S.N. Austad. 2001. Comparative biology of aging in birds: an update. Experimental Gerotology 36:849-883.

Ikeda, K., Nagai, R., Sakamoto, T., Sano, H., Araki, T., Sakata, N., Nakayama, H., Yoshida, M., Ueda, S., and S. Horiuchi. 1998. Immunochemical approaches to AGEstructures: characterization of anti-AGE antibodies. Journal of Immunological Methods 215:95-104.

Iqbal, M., Probert, L.L., and H. Klandorf. 1997. Effect of dietary aminoguanidine on tissue pentosidine and reproductive performance in broiler breeder hens. Poultry Science 76:1574-1579.

Iqbal, M., Probert, L.L., Al-humadi, N.H. and H. Klandorf. 1999a. Protein glycosylation and advanced glycosylation endproducts (AGEs): An avian solution. Journal of Gerontology: Biological Science 54:B1-B6.

Iqbal, M., Kenney, P.B., and H. Klandorf. 1999b. Agerelated changes in meat tenderness and tissue pentosidine: Effect of diet restriction and 
aminoguanidine in broiler breeder hens. Poultry Science $78: 1328-1333$.

Johnsen, A., Lifjeld, J. T., and C. Krokene. 2003. AgeRelated Variation in Mate-Guarding Intensity in the Bluethroat (Luscinia svecica). Ethology 109:147- 158.

Klimkiewicz, M. K. and A. G. Futcher. 1989. Longevity records of North American Birds: Supplement I. J. Field Ornithology. 60(4):469-494.

Kohn, R. R., Cerami, A., and V. M. Monnier V.M. 1984. Collagen aging in vitro by non-enzymatic glycosylation and browning. Diabetes. 33:57-59.

Kohn, R. R., Cerami, A., and V. M. Monnier V.M. 1984. Collagen aging in vitro by non-enzymatic glycosylation and browning. Diabetes 33:57-59.

Kun, R. and F. Weygand. 1937. Chemische Berichte 70:769.

Ledl, F. and E. Schleicher 1990. The Maillard reaction in food and in the human body - new results in chemistry, 
biochemistry and medicine. Angewandte Chemie 102:597626.

Lindstedt, S. L., and W. A. Calde. 1976. Body size and longevity in birds. Condor 78:91-94, 1976.

Maekawa T., Rathinasamy T. K., Altman K. I., and W. F. Forbes. 1970. Changes in collagen with age. The extraction of acid soluble collagens from the skin of mice. Experimental Gerontology 5:177-186.

Maillard, L. C. 1912. Action of amino acids on sugars. Formation of melanoidins in a methodical way. Comptes Rendus de l'Académie des Sciences . 154:66-68.

Makita, Z., Vlassara, H., Rayfield, E., Cartwright, K., Friedman, E., Rodby, R., Cerami, A., and R. Bucala. 1992. Hemoglobin-AGE: a circulating market of advanced glycosylation. Science 258:651-6533.

Maransky, B. P. and K. L. Bildstein. 2002. Follow Your Elders: Age-related Differences in the Migration Behavior of Broad-winged Hawks at Hawk Mountain 
Sanctuary, Pennsylvania. The Wilson Bulletin 113:350353.

Masoro, E. J., M. S. Katz, and C. A. McMahan. 1992. Evidence for the glycation hypothesis of aginag from the food- restricted rodent model. Journal of Gerontology 44:B202-B208.

Masoro, E. J. 1988. Physiological system markers of aging. Experimental Gerontology. 23:391-394.

Monnier V.M, and A. Cerami. 1981. Nonenzymatic browning in vivo: possible process for aging of long-lived proteins. Science 211:491-493.

Monnier V.M., and Cerami A. 1983. Detection of nonenzymatic browining products in the human lens. Biochemica Biophysical Acta. 760:97-103.

Monnier V., M., Kohn R., R., and A. Cerami. 1984. Accelerated age-related browning of human collagen in diabetes mellitus. Proceedings of the National Academy of Sciences of the United States of America $81: 583-587$. 
Monnier, V.M.,R.R. Kohn and A. Cerami. 1994. Accelerated age-related browning of human collagen in diabetes mellitus. Proceedings of the National Academy of Sciences of the United States of America 81:583-587.

Odetti, P., J. Fogarty, D.R. Sell, and V.M. Monnier. 1992. Chromatographic quantitation of plasma and erythrocyte pentosidine in diabetic and uremic subjects. Diabetes 41:153-159.

Payne, R.B. and M.D. Sorenson. 2003. Museum collections as sources of genetic data. Bird Collections in Europe: the Challenge of Mutual Cooperation. Bonner Zoologische Beiträge 51:97-104.

Pickering, S.P.C. 1988. Attendance patterns and behaviour in relation to experience and pair-bond formation in the Wandering Albatross Diomedea exulans at South Georgia. Ibis 131: 183-195.

Pokharna, H. K., V. M. Monnier, B. Boja, and R. W. Moskowitz. 1995. Lysyl oxidase and Maillard reaction- 
mediated crosslinks in aging osteoarthritic rabbit cartilage. Journal of Orthapedic Research 13:13-21.

Rendell M., Stephen P M., Paulsen R., Valentine J L., Rasbold K., Hestorff T., Eastberg S., and D. C. Shint. 1985. An interspecies comparison of normal levels of glycosylated hemoglobin and glycosylated albumin. Comparative biochemistry and physiology. B, Comparative biochemistry 81:819-822.

Sell, D.R. and Monnier, V.M. 1989a. Isolation, purification, and partial characterization of novel flurophores from aging human insoluble collagen-rich tissue. Connective Tissue Research 19:77-92.

Simon, H. and Kraus, A. 1970. Mechanism studies on glycosylamines, sugar hydrazones, Amadori rearrangement products and osazones. Fortschritte der Chemischen Forschung 14:430-471.

Sell, D.R. and Monnier, V.M. 1989b. Structure elucidation of a senescence cross-link from human extracellular matrix. Implication of pentoses in the aging process. Journal of Biological Chemistry 264:21597-21602. 
Sell, D. R. and V. M. Monnier. 1990. End-stage renal disease and diabetes catalyze the formation of a pentose-derived crosslink from aging human collagen. Journal of Clinical Investigation 85:380-4

Sell, D.R., A. Lapolla, P. Odetti, J. Fogarty and V. M. Monnier. 1992. Pentosidine formation in skin correlates with severity of complications in individuals with long-standing IDDM. Diabetes 41:12861291.

Sell, D. R., Lane, M., Johnson, W. A, Masoro, E. J., Mock, 0. B., Reiser, K. M., Fogarty, J. F., Cutler, R. G., Ingram, D.K., Roth, G. S., and V. M. Monnier. 1996. Longevity and the genetic determination of collagen glycoxidation kinetics in mammalian senescence. Proceedings of the National Academy of Science, USA $93: 485-490$.

Sell, D. R., N. R. Kleinman and V. M. Monnier. 2000. Longitudinal determination of skin collagen glycation and glycoxidation rates predicts early death in C57BL/6NNIA mice. The FASEB Journal 14:145-156. 
Smith, C. M., Cooke, F., Robertson, G. J., Goudie, R. I., and W. S. Boyd. 2000. Long-term pair bonds in Harlequin ducks. The Condor 102:201-205.

Suzuki, D., Miyata, T., Saotome, N., Horie, K., Inagi, R., Yasuda, Y., Uchida, K., Izuhara, Y., Yagame, M., Sakai, H., K. Kurokawa. 1999. Immunohistochemical evidence for an increased oxidative stress and carbonyl modification of proteins in diabetic glomerular lesions. Journal of the American Society of Nephrology. 10:822-832.

Strehler, B. L. 1962. Time, cells and aging. Academic Press, New York.

Terres, J. K. 1980. The Audubon Society Encyclopedia of North American Birds. Alfred A. Knopf, New York, NY.

Verzijl., N., Degroot, J., Thorpe, S.R., Bank, R.A., Shaw J.N., Lyons, T.J., Bijlsma, J.W.J., Lafeber, F.P.J., Baynes, J.W., and J. M. TeKoppele. 2000. Effect of collagen turnover on the accumulation of advanced 
glycation end products. Journal of Biological Chemistry 275:39027-39031.

Winker, K. 2000. Obtaining, preserving, and preparing bird specimens. Journal of Field Ornithology 71:250-297. 